[Bull. Agr. Chem. Soc. Japan, Vol. 24, No. 3, p. 326 327, 1960]

\title{
Conversion of D-Glucose to D-Fructose by a Strain of Soil Bacteria
}

Sir :

Marshall and Kool' have described an enzyme in Pseudomonas hydrophila, which catalyses the conversion of D-glucose to D-fructose. The authors now wish to report the finding of a bacterial strain which also has glucose isomerising activity. This strain was isolated from soil, and its microbial characters and ability to isomerise D-glucose were investigated.

The characters of the strain were as follows.

Microscopic observation: Rods, $0.5 \sim 0.7$ by $0.7 \sim 1.2 \mu$, occurring singly. Motile possessing peritrichous tlagella. Gram-negative.

Bouillon agar slant: Grayish-white, smooth, glistening, and spreading growth.

Bouillon agr colonies: Circular, smooth, entire, slightly elevated, and grayish-white.

Bouillon broth: Turbid and slight sediment.

Physiological properties:

Temperature: Good growth at $30^{\circ} \sim 37^{\circ} \mathrm{C}$ and death at $50^{\circ} \mathrm{C}$ in $5 \mathrm{~min}$.

Relation to free oxygen: Facultative anaerobe.

Nitrites produced from nitrates.

Catalase: Positive.

Methyl red test negative; Voges Proskauer test Positive.

Citrates utilization in Koser's medium: Positive.

Milk: Coagulation, and partial peptonization.

Gelatin: Slow liquefaction.

Reduction of dyes: Methylene blue and litmus.

Acid and gas from xylose, arabinose, glucose, fructose, galactose, sucrose, maltose, lactose (slow), trehalose, raffinose, mannitol, dulcitol, sorbitol. Acid slightly and no gas from glycerol. Rhamnose, starch, inuline, and inositol not attacked.

According to Bergey's Manual (6th Ed.), it was concluded that this strain related to Aero-

1) R. O. Marshall and E. R. Kool, Sciance, 125, 648 (1957). bacter cloacae Bergey et al.

Cells grown in $24 \mathrm{hr}$. shake culture at $30^{\circ} \mathrm{C}$ on a synthetic medium ${ }^{2}$ with $\mathrm{D}$-xylose as the sole carbon source were harvested with centrifuge. Reaction experiments to D-glucose with washed living cells, lyophilyzed cells and sonic extract were carried out in the presence of arsenate under the similar conditions with the method of Marshall and Kool. In all cases, the formation of one ketosugar was found in the reaction systems, which reacted in the cysteincarbazole test $^{3)}$ giving a maximum absorption spectra at $560 \mathrm{~m} \mu$. The $R_{F}$ value of the sugar was revealed to be identical with $\mathrm{D}$-fructose and no other sugars were found except added glucose in paper chromatography. The ability of the cells to isomerise D-glucose greatly depended on the sorts of carbon sources in the culture medium, similarly as the investigation by Marshall and Kool, and in the cases of D-glucose and $\mathrm{D}$-fructose as the carbon source, isomerization occurred at very low rate or not.

The ketosugar formed in the reaction system was isolated and confirmed as D-fructose by characterization. In one experiment, the reaction mixture was: Glucose $18 \mathrm{~g}, \mathrm{Na}_{2} \mathrm{HAsO}_{4}$. $7 \mathrm{H}_{2} \mathrm{O} 936 \mathrm{mg}, \mathrm{MgCl}_{2} 203.3 \mathrm{mg}$, washed living cells $1.5 \mathrm{~g}$ (as dry matter), $\mathrm{pH} 7.8$ and final volume $100 \mathrm{ml}$. The mixture was incubated at $38.5 \sim 39^{\circ} \mathrm{C}$ in a closed flask. After incubation for 21,45 , and $68 \mathrm{hr}$, contents of D-fructose determined by the cystein-carbazole method were $17.1,30.0$, and 33.4 per cent respectively on the base of added glucose. The mixture was then deproteinized with $\mathrm{HCiO}_{4}$ and deionized by ion exchange resins, Amberlite IR-120 and Dowex1. Resulted solution was concentrated in vaccum

2) R. M. Hochester and R. W. Watson, Nature, 170, 357 (1952).

3) Z. Dishe and E. Borenfreund, J. Bio!. Chem., 192, 583 (1951). 
and $\mathrm{D}$-fructose was isolated as the insoluble $\mathrm{Ca}$ complex. Then crystallization was carried out in usual way from acetic acid solution and yielded $1.3 \mathrm{~g}$ sugar. Recrystallized products from aqueous ethanol had the following properties : $[\alpha]_{\mathrm{D}}^{20}=-91.2^{\circ}$ (lit. $-92.0^{\circ}$ ); m.p. $100.5^{\circ}$ $\sim 103.5^{\circ} \mathrm{C}$ (lit., $102^{\circ} \sim 104^{\circ} \mathrm{C}$ ). Further investigations are in progress.

The authers wish to express their sincere thanks to Dr. T. Yabuta, Dr. K. Sakaguchi, and Prof. Y. Sakurai of the Univ. of Tokyo, for their encouragement and interest, and also to Mr. K. Komagata of the Institute of Applied Microbiology, Univ. of Tokyo and Mr. H. Machida of the Univ. of Tokyo for their helpful advice in this work.

Nobuzo Tsumura Tomotaro SATo

Food Research Institule,

Ministry of Agriculture and Forestry, Tokyo

Received May 29, 1960

[Bull. Agr. Chem. Soc. Japan, Vol. 24, No. 3, p. 327 328, 1960]

\section{Total Synthesis of $d l$-Deguelin}

Sir :

The Houben-Hoesch' condensation of dihydro$\beta$-tubanol ${ }^{1)}$ (I) $(0.8 \mathrm{~g})$ with methyl 4,5-dimethoxy2-cyanomethylphenoxyacetate ${ }^{2)}$ (II) ( $\left.1.6 \mathrm{~g}\right)$ gave a pale brown resinous matter $(0.6 \mathrm{~g})$, which was able to be separated by fractional recrystallization from aqueous methanol into dihydrodeguelic acid $^{3)}(60 \mathrm{mg})$ (III), m.p. $147 \sim 148^{\circ} \mathrm{C}$, and dihydroisodeguelic acid ${ }^{3)}$ (IV) (250 mg), m.p. $188^{\circ} \mathrm{C}$. III $(500 \mathrm{mg})$ was dissolved in a mixture of acetic anhydride $(10 \mathrm{ml})$ and glacial acetic acid $(0.5 \mathrm{ml})$ and refluxed for twelve minutes in the presence of anhydrous sodium acetate $(200 \mathrm{mg})$. On addition of water $(20 \mathrm{ml})$ brown crystals $(200 \mathrm{mg})$ were obtained, recrystallized from chloroform-ethanol $(2: 3)$ to give dihydrodehydrodeguelin ${ }^{4}$ (V) as faintly yellow crystals, m.p. $262 \sim 265^{\circ} \mathrm{C}$ (decomp.). The mixture of $\mathrm{V}(500 \mathrm{mg})$, N-bromosuccinimide $(260 \mathrm{mg})$ and benzoyl peroxide $(20 \mathrm{mg})$ in carbon tetrachloride $(500 \mathrm{ml})$ was refluxed for twenty minutes. In ten minutes the insoluble crystals

1) R. Huls, Bull. Classe Sci. Roy. Belg., 39, 1064 (1953).

2) A. Robertson, J. Chem. Soc.. 1933, 1163.

3) S. Takei, S. Miyajima and M. Ono, Sci. Patpers Inst. Phys. Chem. Researth, 12, 239 (1933).

4) S. Takei, S. Miyajima and M. Ono, Ber, 66, 1826 (1933). were gradually dissolved and finally the color of the solution changed suddenly to fluorescent yellowish green. The resulted solution was washed with sodium bicarbonate solution and kept to stand for one hour, bright yellow crystals (300 mg) separated, melted at $216^{\circ} \mathrm{C}$ (decomp.), insoluble in every organic solvent except chloroform. Its carbonyl absorption band at $1736 \mathrm{~cm}^{-1}$ suggests a coumarino-chromon structure such as rotenonone. The filtrate afforded a brown solid (160 mg) on evaporation. To the extract of the solid with hot ethanol $(40 \mathrm{ml}) 5 \%$ ethanolic potassium hydroxide solution $(10 \mathrm{ml})$ was added and allowed to stand over night. The separating crystals were recrystallised from ethanol to give dehydrodeguelin ${ }^{4}$ (VI) as pale yellow feather-like crystals (28 mg), m.p. $225 \sim 227^{\circ} \mathrm{C}$. In dioxane solution VI $(2.2 \mathrm{~g})$ was reduced by sodium borohydride $(400 \mathrm{mg})$ to $d l$-deguelol ${ }^{5)}$ (VII) which was recrystallized from chloroformhexane and finally aqueous acetone to afford colorless plates $(500 \mathrm{mg})$, m.p. $180 \sim 180.5^{\circ} \mathrm{C}$, [Found: $\mathrm{C}, 69.59, \mathrm{H}, 6.06$. Calcd. for $\mathrm{C}_{23} \mathrm{H}_{24} \mathrm{O}_{6}$ :

5) Accordins to the private communication, M. Matsui and M. Miyano have performed the partial synthesis of $d l$-deguelin by the oxidation of dl-deguelol, prepared from dehydrodeguelin. 